\title{
Ammonium hydroxide treatment of $A ß$ produces an aggregate free solution suitable for biophysical and cell culture characterization.
}

\begin{abstract}
Alzheimer's disease is the leading cause of dementia in the elderly. Pathologically it is characterized by of the presence of amyloid plaques and neuronal loss within the brain tissue of affected individuals. It is now widely hypothesised that fibrillar structures represent an inert structure. Biophysical and toxicity assays attempting to characterize the formation of both the fibrillar and the intermediate oligomeric structures of $A ß$ typically involves preparing samples which are largely monomeric; the most common method by which this is achieved is to use the fluorinated organic solvent 1,1,1,3,3,3-hexafluoro-2-propanol (HFIP). Recent evidence has suggested that this method is not $100 \%$ effective in producing an aggregate free solution. We show, using dynamic light scattering, size exclusion chromatography and small angle X-ray scattering that this is indeed the case, with HFIP pretreated $A ß$ peptide solutions displaying an increased proportion of oligomeric and aggregated material and an increased propensity to aggregate. Furthermore we show that an alternative technique, involving treatment with strong alkali results in a much more homogenous solution that is largely monomeric. These techniques for solublising and controlling the oligomeric state of $A ß$ are valuable starting points for future biophysical and toxicity assays.
\end{abstract}




\section{Introduction:}

Alzheimer's disease is the leading cause of dementia in the elderly human population. This disease is characterised by neurofibrillary tangles, neuronal death, synapse dysfunction and formation of extracellular amyloid aggregates, ultimately leading to cognitive decline and dementia. Amyloid formation by $A ß$ peptides is characteristic of the disease, forming the major constituent of the plaques that are symptomatic of Alzheimer's disease (Glenner and Wong 1984; Masters et al. 1985). However, the formation of these fibrillar structures is not well correlated with disease severity (McLean et al. 1999), indicating that fibrils represent a relatively non-toxic endpoint in a toxic aggregation pathway (McLean et al. 1999). To reconcile these observations several theories suggesting the presence of soluble, small, oligomeric species of Aß have been developed (Kirkitadze et al. 2002).

There are a number methods for generating small toxic oligomers in vitro (for examples see (Sahoo et al. 2009; Yu et al. 2009; Ahmed et al. 2010; Ryan et al. 2010)), but typically most of these preparations involve the preliminary generation of a stock of $A ß$ which is largely monomeric (Stine et al. 2003). Generally this is a critical requirement for many kinetic studies, as solutions which contain a large number of aggregates will have adverse impacts on understanding how an unfolded form of $A ß$ self-associates into a small nucleus which

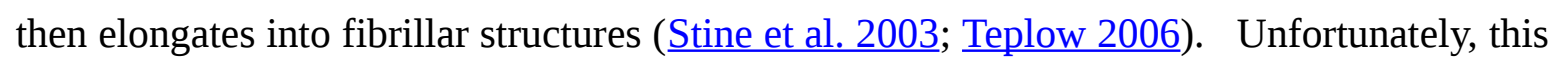
is not a simple process of resuspending lyophilised peptide in the desired buffer, as the hydrophobic nature of the peptide makes the initial dissolution very difficult (Teplow 2006). Furthermore $A ß$ appears to have a structural memory, reforming the conformations that it had adopted prior to lyophilisation (

To avoid these issues many researchers resort to a variety of solubilisation agents, including strong alkali and acids (Zagorski et al. 1999; Fezoui et al. 2000; Teplow 2006), dimethylsulfoxide (DMSO) (Shen and Murphy 1995; Lambert et al. 2001; Broersen et al. 2011), chaotropic salts and fluorinated alcohols, such as trifluroethanol (Zagorski and Barrow 1992) and hexafluoroisopropanol (HFIP) (Stine et al. 2003; Broersen et al. 2011). The most commonly adopted approach is to use HFIP (thought to induce alpha helical conformations, produce monomeric solutions and remove the conformational memory from the peptide) followed by removal of HFIP and resuspension using an aqueous compatible resuspension solvent such as DMSO (Walsh et al. 1997; Stine et al. 2003; Williams et al. 2010). Recently, the use of HFIP has been suggested by a number of groups to cause 
heterogeneity in the starting peptide self-association state (Nichols et al. 2005; $\underline{\text { Nichols et }}$ al. 2005; Pachahara et al. 2012), which may cause enhanced aggregation.

We show using a variety of methods, including thioflavin T (ThT) binding, Small Angle X-ray scattering (SAXS), dynamic light scattering (DLS) and size exclusion chromatography measurements, that HFIP pretreatment affects the aggregation state and kinetics of amyloid formation of the resuspended peptide. We also show that the use of ammonium hydroxide, as an initial treatment, greatly aids solubility and produces a relatively less aggregated and seed free peptide solution, which is important for understanding the process of $A ß$ self-association and hence neuronal cell toxicity.

\section{Materials:}

Human $A \aleph_{1-42}$ (from this point referred to as $A \S_{42}$ ) was synthesised and purified by Dr. James I. Elliott at Yale University (New Haven, CT) using tBOC chemistry with DCC and HOBT coupling reagents. The correct unmodified sequence was verified by mass spectrometry. 1,1,1,3,3,3-hexafluoro-2-propanol (HFIP) was obtained from Oakwood Products Inc. (West Columbia, SC), analytical grade ammonium hydroxide $\left(\mathrm{NH}_{4} \mathrm{OH}\right)(28 \% \mathrm{v} / \mathrm{v})$, trifluoroacetic acid (TFA, 99\%) and staurosporine from Streptomyces sp. were from Sigma Chemical Co (St Louis, MO). PolyLlysine coated 96well plates were from BD (Franklin Lakes, NJ Cat. No. 356516). The F12K media, horse serum, penicillin, streptomycin, amphotericin B and trypsin/EDTA were from Invitrogen (Grand Island, NY). Foetal bovine serum (FBS) was from SAFC Biosciences (Lenexa, KS). Human recombinant ßnerve growth factor (NGF) was purchased from Sino Biological Inc. (Beijing, P.R. China). The cell counting kit-8 (CCK-8) reagent was from Dojindo Molecular Technologies, Inc. (Kumamoto, Japan). All reagents otherwise not indicated were of analytical grade.

\section{Methods:}

\section{$\mathrm{A} \beta \mathrm{HFIP}$ and $\mathrm{NH}_{4} \mathrm{OH}$ pretreatment:}

Synthetic human $A \beta_{42}$ peptide was prepared in two separate ways. Firstly the $A \beta_{42}$ lyophilised powder was dissolved in TFA and dried under a nitrogen stream. The remaining film was dissolved in 100\% HFIP to a concentration of $1 \mathrm{mg} / \mathrm{ml}$, sonicated $5 \mathrm{~min}$ in a bath sonicator and dried under a nitrogen stream. The HFIP treatment was repeated twice more and on final dissolving the peptide was dispensed into microcentrifuge tubes. After drying under a nitrogen stream, the peptide was further dried under vacuum for $12 \mathrm{hr}$ to give a clear film. 
The second method was to take the original peptide and dissolve it in $10 \%$ (w/v) $\mathrm{NH}_{4} \mathrm{OH}$ at $0.5 \mathrm{mg} / \mathrm{ml}$. The peptide was incubated for $10 \mathrm{~min}$ at room temperature followed by sonication $(5 \mathrm{~min})$ and then dispensed $(0.5 \mathrm{ml})$ into microfuge tubes. The $\mathrm{NH}_{4} \mathrm{OH}$ was removed by lyophilisation to yield a salt free fluffy white peptide. All aliquots from both methods were then stored at $-80^{\circ} \mathrm{C}$. Immediately prior to use, the HFIP and $\mathrm{NH}_{4} \mathrm{OH}$ treated and untreated $A \beta_{42}$ were dissolved in $60 \mathrm{mM} \mathrm{NaOH}$ and the concentration determined by absorbance at 214 and 280nm using extinction coefficients of $76848 \mathrm{M}^{1} \mathrm{~cm}^{1}$ or 1490 $\mathrm{M}^{-1} \mathrm{~cm}^{-1}$, respectively. In all cases the resuspended peptide was analysed by mass spectrometry and the peptide found to be unmodified with no trace of HFIP or $\mathrm{NH}_{4} \mathrm{OH}$.

Thioflavin T assay:

The ThT assays were conducted as described previously (McColl et al. 2009; $\underline{\text { Ryan et al. }}$ 2012), Briefly, $A \beta_{42}$ reconstituted in $60 \mathrm{mM} \mathrm{NaOH}$ to a stock concentration $\sim 200 \mu \mathrm{M}$ was diluted to a final concentration of $5 \mu \mathrm{M}$ in phosphate buffered saline (PBS, $136.89 \mathrm{mM} \mathrm{NaCl}$, $2.68 \mathrm{mM} \mathrm{KCl}, 6.39 \mathrm{mM} \mathrm{Na} 2 \mathrm{PO}_{4}, 1.47 \mathrm{mM} \mathrm{KH}_{2} \mathrm{PO}_{4}$ ) pH 7.4 containing $30 \mu \mathrm{M}$ ThT. Vehicle controls of $60 \mathrm{mM} \mathrm{NaOH}$ were used to confirm that the typical dilution of between 1 in 50 to1 in 200 did not significantly alter the $\mathrm{pH}$ of the PBS solution. The samples were dispensed $(200 \mu \mathrm{l})$ into a 96 well clear bottom plate and placed in a Flexstation 3 plate reader, incubated at $37{ }^{\circ} \mathrm{C}$ with agitation every $7 \mathrm{~min}$. The ThT fluorescence was measured every $7 \mathrm{~min}$ for $24 \mathrm{hr}$ using excitation and emission wavelengths of 440nm and 485nm, respectively.

\section{Transmission Electron Microscopy (TEM)}

Carbon-coated 300-mesh copper grids were glow-discharged in nitrogen to render the carbon film hydrophilic. Samples were gently agitated, before pipetting ( $4 \mu \mathrm{l})$ onto the grids. After $30 \mathrm{sec}$ adsorption time, the excess was drawn off using Whatman 541 filter paper. The grids were stained with $2 \% \mathrm{w} / \mathrm{v}$ potassium phosphotungstate, $\mathrm{pH} 7.2$, for 10 sec. Grids were air-dried before examination. The samples were examined using a Tecnai 12 Transmission Electron Microscope (FEI, Eindhoven, The Netherlands) at an operating voltage of $120 \mathrm{KV}$. Images were recorded using a Megaview III CCD camera and AnalySIS camera control software (Olympus).

\section{Dynamic light scattering:}


For dynamic light scattering (DLS) experiments the $\mathrm{A} \beta_{42}$ dissolved in $60 \mathrm{mM} \mathrm{NaOH}$ (Stock concentration $500 \mu \mathrm{M}$ ) was diluted into $50 \mathrm{mM}$ Tris $\mathrm{pH} 8.0$ buffer containing $10 \mathrm{mM}$ EDTA to a final concentration of $100 \mu \mathrm{M}$. This buffer was chosen to minimise aggregation as $A ß$ aggregates at a slower rate at this $\mathrm{pH}$ and EDTA was included to prevent metal induced aggregation (Huang et al. 2004). Thus, the aggregation state of the resuspended material was not expected to change significantly during the time taken to prepare the peptide for DLS measurements. Vehicle controls were prepared at the concentrations used in the $A \beta_{42}$ experiments. The $\mathrm{pH}$ of all reactions were checked to be $\mathrm{pH}$ 8.0. All reaction mixtures were filtered through a $0.2 \mu \mathrm{m}$ syringe filter before the concentration of the sample was measured to determine the degree of peptide loss during filtration. In all cases the concentration of peptide changed less than 5\%. Subsequently, $20 \mu \mathrm{l}$ of the filtrate was loaded in quadruplicate into a Greiner 384-well low volume glass bottom plate. The plate was centrifuged ( $5 \mathrm{~min}, 1000 \mathrm{x}$ g) to pellet any remaining larger insoluble material prior to measurement. A total time of 20 min elapsed between the addition of the $A \beta_{42}$ to the buffer and the acquiring of data from the plate.

The DLS measurements were taken at $25{ }^{\circ} \mathrm{C}$ using a Dyna Pro Nano Star plate reader at the Bio21 Collaborative Crystallisation Centre at laser wavelength $830 \mathrm{~nm}$, with temperature control capacity and auto-attenuation function. To ensure accurate readings, the final distribution was taken from an accumulation of 50 individual, 5 second DLS collections. Hydrodynamic radius $\left(\mathrm{R}_{\mathrm{h}}\right)$ was calculated from the diffusion coefficient by the Stokes-Einstein relationship.

\section{Size Exclusion Chromatography (SEC):}

For SEC measurements the $\mathrm{A}_{42}$ stock in $60 \mathrm{mM} \mathrm{NaOH}$ was diluted into PBS to a final concentration of $200 \mu \mathrm{M}$ and incubated at $25^{\circ} \mathrm{C}$ for 20 minutes. The samples were centrifuged (5 min, 16,500 x g) immediately before loading onto a S200 Superdex column (GE, 10/300 GL). The column was eluted with $50 \mathrm{mM}$ Tris $\mathrm{pH} 8.0$ at a flow rate of $0.5 \mathrm{ml} / \mathrm{min}$ for 1.5 column volumes. The elution of proteins was measured using a flow cell absorbance detector set at $280 \mathrm{~nm}$. Molecular weight was estimated by comparison to the SEC protein calibrants (GE Healthcare).

Small- angle $X$-ray scattering (SAXS) measurements

A slightly modified approach for solubilising the treated $A \beta_{42}$ was used for SAXS measurements, whereby the lyophilised peptide (either treated with HFIP or $\mathrm{NH}_{4} \mathrm{OH}$, and 
typically in 3-4 mg aliquots) was taken up in $20 \mu \mathrm{l}$ of $60 \mathrm{mM} \mathrm{NaOH}$, which was immediately diluted to $13 \mathrm{mM} \mathrm{NaOH}$ with distilled water. This sample was sonicated for $5 \mathrm{~min}$ in a bath sonicator to ensure the peptide entered the solution at the lower concentration of $\mathrm{NaOH}$. The sample was then neutralised with 10X PBS, resulting in a solution with a $\mathrm{pH}$ of 7.4, and centrifuged at $16,500 \mathrm{x} \mathrm{g}$ in a benchtop microcentrifuge for $10 \mathrm{~min}$. The $214 \mathrm{~nm}$ absorbance of the supernatant was measured to determine concentration using the above quoted extinction coefficient. Typically this process resulted in stock solutions of approximately $5-7 \mathrm{mg} / \mathrm{ml}(1300-1500 \mu \mathrm{M})$. No difference in the kinetics of fibril formation, as measured by ThT fluorescence, were observed for direct dilution from $60 \mathrm{mM} \mathrm{NaOH}$ or $13 \mathrm{mM} \mathrm{NaOH}$.

SAXS measurements were acquired at the SAXS/WAXS beamline of the Australian Synchrotron (Clayton, Victoria, Australia). $\mathrm{A} \S_{42}$ solutions, made using untreated, HFIP treated and $\mathrm{NH}_{4} \mathrm{OH}$ treated lyophilised peptide, solubilised using the above described $\mathrm{NaOH}$ solubilisation protocol $(1 \mathrm{mg} / \mathrm{ml}, 221 \mu \mathrm{M})$ were analysed at a camera length of 3.3 metres corresponding to a range of momentum transfer $0.005 \leq \mathrm{q} \leq 0.35 \AA^{-1}$ (where $\mathrm{q}=$ $4 \pi \sin \theta / \lambda, 2 \theta$ is the scattering angle and $\lambda$ is the $\mathrm{X}$-ray wavelength: $1.03 \AA$ at $12 \mathrm{KeV}$ ), using a Pilatus $1 \mathrm{M}$ camera (Dectris, Switzerland). Data were normalised using an integrated beamstop and intensities put on an absolute scale using distilled water as a standard. To limit radiation damage, $50 \mu \mathrm{l}$ samples/buffers were flowed through a $1.5 \mathrm{~mm}$ quartz capillary and 10 frames of 1 second exposure collected. The individual frames were compared for agreement before being averaged with the scatterBrain IDL program, downloaded from the Australian synchrotron SAXS/WAXS beam line website (http://www.synchrotron.org.au/).

SAXS data were analysed using Primus (Konarev et al. 2003) from the ATSAS (Petoukhov et al. 2007; Petoukhov et al. 2012) software suite (www.embl-hamburg.de/biosaxs/software.html), which was used to plot the data and create Kratky plots. A Kratky plot, is a plot of Intensity (I) multiplied by the square of the scattering vector, $s$, (defined as equal to $4 \pi \sin (\theta) / \lambda$, where $2 \theta$ is the total scattering angle and $\lambda$ is the wavelength of the $\mathrm{x}$-ray) against s (Doniach 2001).

$A \beta_{1-42}$ toxicity in cell culture

Rat pheochromocytoma (PC12) cells were maintained and passaged every 3-4 days in PC12 media (F12K media containing 15\% (v/v) horse serum, 2.5\% (v/v) fetal bovine serum (FBS), $100 \mathrm{U} / \mathrm{ml}$ penicillin G sodium, $100 \mu \mathrm{g} / \mathrm{ml}$ streptomycin sulfate and $0.25 \mu \mathrm{g} / \mathrm{ml}$ PeerJ reviewing PDF | (v2012:11:75:2:0:NEW 16 Apr 2013) 
amphotericin B. The PC12 cells (passage 5-15) were trypsinised (0.05\% (w/v) trypsin/0.48 mM EDTA in PBS) and harvested in the maintenance media. The cells were centrifuged (400×g, $5 \mathrm{~min}$ ) and the cell pellet was resuspended in F12K media containing 0.5\% (v/v) FBS, $100 \mathrm{U} / \mathrm{ml}$ penicillin G sodium, $100 \mu \mathrm{g} / \mathrm{ml}$ streptomycin sulfate and $0.25 \mu \mathrm{g} / \mathrm{ml}$ amphotericin B. The centrifugation step was repeated and the cell pellet was resuspended in the media containing $0.5 \%(\mathrm{v} / \mathrm{v})$ FBS with the addition of $100 \mathrm{ng} / \mathrm{ml}$ NGF. The cells were seeded at $5 \times 10^{3}$ cells/well (100 $\mu \mathrm{l} /$ well) into the inner 60 wells of a 96 well plate coated with polyLlysine. The outer 36 wells were used as a moat and were filled with sterile water $(100 \mu \mathrm{l} /$ well $)$. The cultures were maintained at $37{ }^{\circ} \mathrm{C}$ with $5 \% \mathrm{CO}_{2}$ in a humidified incubator (Heraeus Hera cell 150, Kendro Laboratory Products, Langenselbold, Germany) and allowed to differentiate for $96 \mathrm{~h}$ before treating with $\mathrm{A} \aleph_{42}$.

The HFIP- or $\mathrm{NH}_{4} \mathrm{OH}$-treated peptide were prepared as described for the SAXS measurements, except $0.5 \mathrm{mg}$ of $\mathrm{A} ß$ was reconstituted using $60 \mathrm{mM} \mathrm{NaOH}$, sterile water and 10 x Dulbecco's PBS consisting of $1368.9 \mathrm{mM} \mathrm{NaCl}, 26.8 \mathrm{mM} \mathrm{KCl}, 63.9 \mathrm{mM} \mathrm{Na} 2 \mathrm{PO}_{4}$, $14.7 \mathrm{mM} \mathrm{KH}_{2} \mathrm{PO}_{4} 9.0 \mathrm{mM} \mathrm{CaCl}_{2}$ and $4.9 \mathrm{mM} \mathrm{MgCl}_{2}$ (Dulbecco and Vogt 1954) instead of the standard laboratory reagents. The resulting Aß peptide was assessed for concentration as described for the SAXS measurements. This process resulted in Aß stock solutions of 180-250 $\mu \mathrm{M}$. The concentrated peptide was diluted into the cell culture media A (F12K, 0.5\% FCS, $100 \mathrm{ng} / \mathrm{ml} \mathrm{NGF}, 100 \mathrm{U} / \mathrm{ml}$ penicillin G sodium, $100 \mu \mathrm{g} / \mathrm{ml}$ streptomycin sulfate and $0.25 \mu \mathrm{g} / \mathrm{ml}$ amphotericin B) at no more than $1 / 10$ so as not to affect the composition of the culture media. The vehicle was prepared in the culture media using the same dilution as the peptide. The media/vehicle was used to make subsequent dilutions of the peptide $(1020 \mu \mathrm{M})$. Cultures were also treated with the toxin control, staurosporine $(1 \mu \mathrm{M})$.

The cultures were incubated and assessed for viability after 48, 72 and $96 \mathrm{~h}$ using the CCK8 reagent. Five minutes prior to the assay, a second toxin control $(0.1 \%(\mathrm{v} / \mathrm{v})$ Triton $\mathrm{X} 100$ ) was added to the designated cells. The viability assay was done by aspirating the treatment media and replacing with cell culture media A containing $10 \%$ of the CCK8 reagent $\left(100 \mu \mathrm{l} /\right.$ well). The cultures were incubated for $2 \mathrm{~h}$ at $37^{\circ} \mathrm{C}$ and then measured for absorbance changes on the LabSystems Multiskan MS multiplate reader (ThermoFisher Scientific, Scoresby, Australia) using a $405 \mathrm{~nm}$ filter. Wells containing CCK8 reagent and no cells were used to measure the background absorbance of the CCK8/media and the values were subtracted from the test data. The absorbance readings for the untreated cells were normalised to $100 \%$ to adjust for variation between control values of individual experiments and the test data were expressed as a proportion of the untreated cells. The PeerJ reviewing PDF | (v2012:11:75:2:0:NEW 16 Apr 2013) 
normalised data represent the mean and standard error of the mean (SEM) from 2-4 experiments. The normalised comparisons and the results were taken to be significant when the $p$ value was below 0.05. The ANOVA and comparisons were done in a Microsoft ${ }^{\circledR}$ Office Excel spreadsheet.

\section{Results:}

\section{Effect of solubilisation pretreatment method on Aß amyloid formation.}

The effect of HFIP treatment on amyloid formation by $A \beta_{42}$ peptides was investigated using a continuous ThT assay. ThT fluorescence was measured for solutions containing untreated, HFIP or $\mathrm{NH}_{4} \mathrm{OH}$ pretreated $\mathrm{A} \beta_{42}$ (Figure 1A) and resuspended using the standard $\mathrm{NaOH}$ protocol. The ThT fluorescence timecourse of untreated $A \beta_{42}$ was variable with an average $t^{1} / 2$ of approximately $14.9 \pm 2.6 \mathrm{hr}$ (Figure 1A). Pretreatment with HFIP decreased the $t^{1 / 2}$ by $6 \mathrm{hr}$ to approximately $9 \pm 1.9 \mathrm{hr}$, while $\mathrm{NH}_{4} \mathrm{OH}$ pretreatment increased the average $t \frac{1}{2}$ to approximately $16.2 \pm 1.3 \mathrm{hr}$. In all cases we observe an initial increase in the ThT fluorescence intensity over the first hour, equivalent to approximately 10 arbitrary units, which is within the background of the timecourse assay and does not differ with $A ß_{42}$ treatment. This increase could be attributed to a number of early events, ranging from temperature equilibration in the instrument through to the formation of cross- $ß$ sheets structures and early oligomers.

\section{Aggregation state of Aß after dissolution.}

Due to the observed increase in the rate of fibril formation that occurs with HFIP pretreatment, we hypothesised that this solvent was not completely removing the oligomers, but was in fact allowing amyloid seeds to persist through the complete removal of HFIP and thereby accelerate aggregation and fibril formation. To investigate the starting aggregation state of $A \S_{42}$ in solution we used dynamic light scattering, size exclusion chromatography and small angle x-ray scattering. DLS was used to investigate qualitative differences in the preparation techniques. DLS provides an approximate hydrodynamic radius based on the ability of a solution to scatter light and is sensitive to the presence of aggregates. While hydrodynamic radius is typically applied to spherical particles, in this case the approximate radius is sufficient to indicate a qualitative difference between the two treatments. The DLS measurements on average demonstrated that both the HFIP and $\mathrm{NH}_{4} \mathrm{OH}$ treated $\mathrm{A} \beta_{42}$ exist as a monomodal polydisperse solution (Figure 2A) however, the spread of data for both samples was quite wide, with the extremes of low and high PeerJ reviewing PDF | (v2012:11:75:2:0:NEW 16 Apr 2013) 
distributions shown in the supplementary data (Supp 1). For the HFIP preparations we found a large degree of variability in the average distribution of five separate experiments with polydispersity factors ranging from $10 \%-52 \%$ and radii ranging from 3-100 nm (Figure 2A, red line). Given this variability, the most commonly observed average radius was $8 \mathrm{~nm}$ with approximately $50 \%$ polydispersity. In contrast, $A \beta_{42}$ pretreated with $\mathrm{NH}_{4} \mathrm{OH}$ was more consistent, with the average distribution of five separate experiments showing radii ranging from $1-10 \mathrm{~nm}$ and $30 \%$ polydispersity factors. The average radius of this sample was $3.5 \mathrm{~nm}$ with 30\% polydispersity (Figure 2A).

Size exclusion analysis (Figure 2B) of HFIP and $\mathrm{NH}_{4} \mathrm{OH}$ pretreated $\mathrm{A}_{42}$ were consistent with the findings of the DLS experiments (Figure 2A). We observed that the treatment of $A \aleph_{42}$ with HFIP had an elution profile that displayed a heterogeneous mix of species, ranging in elution volume from $8.5 \mathrm{ml}$ (the void volume of the column) to approximately $20 \mathrm{ml}$ (the total volume of the column) indicating a large range of species. Using the area under the peaks to estimate the percentage of protein present, the major peaks from the HFIP pretreated peptide occur at $8.5 \mathrm{ml}$ ( $\sim 65 \%$ total protein) and $17 \mathrm{ml}$ ( 20\% total protein) indicating the presence of monomeric ( $\sim 5,000 \mathrm{Da})$ and large oligomeric species (MW greater than 80,000 Da). For $\mathrm{NH}_{4} \mathrm{OH}$ pretreated $\mathrm{A}_{42}$ we observed a different bimodal distribution with a major ( 90\% total protein) monomeric peak (MW 5,000 Da) eluting at $17 \mathrm{ml}$ and a second minor ( 10\% total protein) peak eluting at $12 \mathrm{ml}$, corresponding to a medium sized oligomeric species (MW 40,000-50,000Da).

Electron microscropy of the preparation techniques.

Aß prepared for the ThT and SEC assays were analysed by TEM. Micrographs show that after $6 \mathrm{~h}$ at $37^{\circ} \mathrm{C}$ the $A \beta_{42}$ pretreated with HFIP has more protofibril/early fibril structures compared with the $\mathrm{A} \beta_{42}$ pretreated with $\mathrm{NH}_{4} \mathrm{OH}$ (Figure $3 \mathrm{~A} \& \mathrm{~B}$ ). The smaller structures of the latter are beyond the sensitivity of this technique (Figure $3 \mathrm{~B}$ ). In light of the differing buffer conditions used for DLS, the HFIP and $\mathrm{NH}_{4} \mathrm{OH}$ pretreated $\mathrm{A}_{42}$ prepared for DLS were also analysed by TEM (Figure 3 C \& D). The representative micrographs show that some short fibrils are present in the HFIP pretreated $A \aleph_{42}$ solution (Figure 3C), whilst only small, unidentifiable structures are present in the $\mathrm{NH}_{4} \mathrm{OH}$ pretreated peptide solution (Figure 3D).

\section{Small angle $\mathrm{X}$-ray scattering of $\mathrm{HFIP}$ or $\mathrm{NH}_{4} \mathrm{OH}$ pretreatment}

In addition to the DLS and SEC measurements, we also investigated the initial aggregation state by SAXS measurements (Figure 3). A comparison of the SAXS data of the untreated (Figure 4A), HFIP treated (Figure 4B) and $\mathrm{NH}_{4} \mathrm{OH}$ treated (Figure 4C) $\mathrm{A} \beta_{42}$ highlights the PeerJ reviewing PDF | (v2012:11:75:2:0:NEW 16 Apr 2013) 
different solution behaviour of these samples. The data indicates that all of the peptide solutions contained a polydisperse mix of aggregates, as the data in the low q region of the scattering curves displays a significant increase in intensity, highlighted in Figure 4D. This makes interpretation of the SAXS data in terms of shape or molecular weight difficult as the scattering from the aggregated material significantly distorts the analysis, however we can transform the data into a Kratky plot, which can give an indication of the folded/unfolded state of a protein (Doniach 2001; Mertens and Svergun 2010), with folded proteins typically showing a prominent peak in the curve, while unfolded proteins show a continuous increase as $s$ increases (for review of the basis of Kratky plots and on the analysis of SAXS data see (Doniach 2001; Putnam et al. 2007)). The treated and untreated $\mathrm{A} \beta_{42}$ show a qualitative difference in the potential degree of folded peptide represented by the scattering curves (Figure $4 \mathrm{E}$ ). $\quad \mathrm{NH}_{4} \mathrm{OH}$ pretreated $\mathrm{A} \beta_{42}$ shows a completely unfolded structure, whilst HFIP pretreated peptide appears to represent partially folded species (Figure 4E). The untreated peptide is intermediate in the degree of folded and unfolded peptide compared to HFIP and $\mathrm{NH}_{4} \mathrm{OH}$ treatment.

The effect of pretreatment on cellular toxicity.

Pretreatment of $A \S_{42}$ has a large impact on the oligomerisation state of $A \S_{42}$, which is a key factor for toxicity in vitro. A CCK8 toxicity assay was used to investigate how the $A \S_{42}$ preparation method affects toxicity in PC12 cultures after 24-96 h. Cultures treated with both $\mathrm{NH}_{4} \mathrm{OH}$ and HFIP pretreated $\mathrm{A}_{42}(15-20 \mu \mathrm{M})$ were viable after $48 \mathrm{~h}$ (Figure $5 \mathrm{~A}$ ). Compared with vehicle treated cells, the PC12 cultures treated with $\mathrm{NH}_{4} \mathrm{OH}$ pretreated $\mathrm{A}_{42}(15$ and $20 \mu \mathrm{M})$ for $72 \mathrm{~h}$ showed a 15.7\% $(P<0.001)$ and 30.2\% $(P<0.001)$ decrease in viability, respectively (Figure 5B). In contrast, PC12 cultures treated with the HFIP pretreated A $\S_{42}$ $(10-20 \mu \mathrm{M})$ for $72 \mathrm{~h}$ did not show any loss of viability (Figure 5B). However, the PC12 cultures treated with the HFIP pretreated $A ß$ for $96 \mathrm{~h}$, were $38.4 \%(P<0.001)$ less viable than vehicle treated cells but only at the highest concentration tested (20 $\mu \mathrm{M}$, Figure $5 \mathrm{C})$. After $96 \mathrm{~h}$, the PC12 cultures treated with the $\mathrm{NH}_{4} \mathrm{OH}$ pretreated $\mathrm{Aß}(15$ and $20 \mu \mathrm{M})$ showed a 25.2\% $(P<0.001)$ and $42.1 \%(P<0.001)$ decrease in viability, respectively compared with vehicle treated cells (Figure 5C).

\section{Discussion:}

Fluorinated alcohols such as HFIP are widely used to break beta sheet structure and induce alpha helical conformations (Hirota et al. 1997; Buck 1998). These solvents have been used to inhibit processes involving beta sheet formation, mainly relating to amyloid aggregation (Zagorski and Barrow 1992; Buck 1998; Stine et al. 2003). The exact protocol PeerJ reviewing PDF | (v2012:11:75:2:0:NEW 16 Apr 2013) 
for the use of these solvents appears to vary dramatically. However, most protocols describe an initial incubation with HFIP followed by evaporation to dryness and suspension of the resulting film with some other solvent. Common examples of the secondary solvent

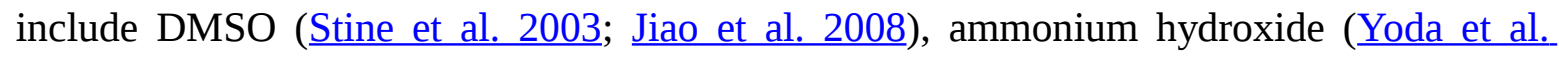
2008) or sodium hydroxide (Ciccotosto et al. 2011). In other cases the HFIP is not removed until after dissolution into aqueous buffer (for example (Kayed et al. 2004)), but this protocol is believed to be flawed as there is extensive evidence that low concentrations of HFIP are ineffective at dissociating oligomers (Lesne et al. 2006) and can actually enhance fibril formation (Nichols et al. 2005; Rangachari et al. 2006).

Despite the use of HFIP for the purposes of erasing conformational memory, there is little understanding of whether or not disaggregation is maintained during the removal of the HFIP from the $A ß$ sample and film formation. Previous work on Aß peptide film formation from HFIP solutions suggests that producing a film of the peptide results in accumulation of a variety of aggregated structures (Pachahara et al. 2012). Moreover, it has been suggested that HFIP disaggregation of Aß peptides is also inconsistent, with a DLS study showing that the peptide can self-associate within the HFIP solution (Fulop et al. 2006).

In this study, we have determined that HFIP pretreatment and film formation has adverse effects on the subsequent aggregation of $A \aleph_{42}$ in an aqueous buffer system. Our study shows that HFIP treatment followed by sodium hydroxide resuspension adversely affects the starting aggregation state of the resuspended peptide, inducing a large proportion of small aggregates, otherwise unidentifiable by TEM but quantifiable by SEC, DLS and SAXS measurements. Interestingly, the starting aggregation state was consistently worse with HFIP pretreated $A ß_{42}$ independent of the secondary buffer used for biophysical analysis including both Tris. $\mathrm{HCl}$ pH 8.0 and PBS pH 7.4, indicating that buffer composition and $\mathrm{pH}$ 7.4-8.0 had little impact on the initial aggregation state. The large proportion of aggregate in the HFIP pre-treated $A \aleph_{42}$ increases the kinetics of amyloid fibril formation, presumably due to increased number of nucli for fibril formation at $\mathrm{t}=0$. Similar to the observation of Stine et al (Stine et al. 2003), the peptide films produced from HFIP treatment were difficult to resuspend consistently, leading to large variations in the concentration of the stock solution of peptide (data not shown). In contrast, treatment of $\mathrm{A} ß$ with $\mathrm{NH}_{4} \mathrm{OH}$ results in fluffy white powder that yields consistent concentrations of $\mathrm{A} ß$ stock solutions (CV 10-15\% based on the starting weight of the peptide). 
Strong alkalis such as ammonium hydroxide, which do not approach the pI of Aß (pI 5) upon neutralisation, have been widely used as initial solubilisation agents for synthetic and ex vivo peptides. Solubilisation of amyloid by alkali has long been known to be effective, with the earliest report of its use in the isolation of amyloid from tissue samples occurring in 1898 (Krakow 1898), followed by several other reports of the use of barium hydroxide, ammonium hydroxide, sodium hydroxide, calcium hydroxide, alkaline borate and alkaline buffered phosphate for solubilisation and analysis of amyloid deposits in tissue samples (Shirahama and Cohen 1967; Pras et al. 1969; Perry et al. 1981; Dubois et al. 1999). In particular, sodium and ammonium hydroxides were observed to be the most effective in both preventing aggregation and disaggregating fibrillar structures (hirahama and Cohen 1967). More recently, ammonium hydroxide has been found to be of use in HPLC analysis of synthetic Aß peptides, where buffering the samples with $0.2 \%$ ammonium hydroxide results in improved peak shape, retention and sample recovery (Lame et al. 2011). Furthermore, ammonium hydroxide pretreatment has been shown previously to be of use in producing homogenous solutions of $A ß$ consisting primarily of low molecular weight species by Fezoui et al (Fezoui et al. 2000; Fezoui and Teplow 2002; Teplow 2006). As initial pretreatment buffers, the aforementioned studies used $2 \mathrm{mM}$ $\mathrm{NaOH}$ for $A \aleph_{40}$ or $10 \mathrm{mM} \mathrm{NH} 4 \mathrm{OH} / 6 \mathrm{M}$ guanidine. $\mathrm{HCl}$ for both $\mathrm{A} \aleph_{40}$ and $A \beta_{42}$ and the analytical techniques included fourier transform infrared spectroscopy, circular dichroism, atomic force microscopy, congo red binding, SEC, electron microscopy and neurotoxicity. Hence, our study is the first to directly compare HFIP to $\mathrm{NH}_{4} \mathrm{OH}$ pretreated $A \S_{42}$ using analytical techniques including ThT binding, DLS, SEC, SAXS, electron microscopy and neuronal cell viability. We found that ammonium hydroxide pretreatment and lyophilisation typically resulted in an $A \S_{42}$ peptide residue that resembled "fairy floss". This lyophilised peptide resuspended extremely well when subjected to the sodium hydroxide resuspension protocol described in the methods section and the SAXS, DLS, SEC and electron microscopy analyses all indicated that the resulting solution contained a much lower proportion of structured aggregated material. The ThT analysis of the rate of aggregation indicated that the $\mathrm{NH}_{4} \mathrm{OH}$ pretreated $\mathrm{A}_{42}$ gives consistent amyloid fibril formation kinetics, which were marginally slower then those of the untreated $A \S_{42}$ peptide, suggesting that this protocol does not increase the amyloid forming potential of the starting solution. This treatment protocol also decreased the variability in aggregation rate observed with the untreated peptide, with independent experiments producing differences in $t^{1 / 2}$ of $5.2 \mathrm{hr}$ and $2.6 \mathrm{hr}$ for untreated and $\mathrm{NH}_{4} \mathrm{OH}$ treated peptide, respectively. In contrast to DMSO PeerJ reviewing PDF | (v2012:11:75:2:0:NEW 16 Apr 2013) 
solvent, $\mathrm{NH}_{4} \mathrm{OH}$ has the advantage of being more compatible with analytical methods because low amounts of DMSO can interfere with UV absorbance measurements. In addition 0.5-1\% DMSO is toxic to hippocampal neuronal cultures (ㅂanslick et al. 2009) and has some potentially adverse effects on $A ß$ including denaturation (Jackson and Mantsch 1991), inhibition of Aß aggregation (Shen and Murphy 1995) and inhibition of Aß oxidative processes (Davis et al. 2011).

As observed by DLS, SEC and SAXS, the composition of the soluble material is different between the two pre-treatments (HFIP A $\beta_{42}$ has higher molecular weight aggregates compared with the $\mathrm{NH}_{4} \mathrm{OH}$ material). The HFIP pretreated $A \beta_{42}$ had a faster propensity to aggregate in the ThT assay (Figure 1). The HFIP pretreated $A \beta_{42}$ was less toxic to PC12 cultures compared with $\mathrm{NH}_{4} \mathrm{OH}$ pretreated $\mathrm{A} \beta_{42}$ at 72 and $96 \mathrm{~h}$ posttreatment (Figure 5). These data suggest that the HFIP and $\mathrm{NH}_{4} \mathrm{OH} \mathrm{A} \beta_{42}$ may interact with the cell differently including differences in peptide affinity for the cell membrane, thereby affecting the toxicity. These data are consistent with the $\mathrm{NH}_{4} \mathrm{OH}$ material transitioning through a toxic intermediate, while the HFIP treated peptide appears to require extra time to develop toxicity. We hypothesise that the reduced toxicity of HFIP treated peptide is due to a decreased availability of effective (toxic) $A \beta_{42}$ because it is terminally trapped upon dissolution in a variety of non-toxic structures. Additionally, the observed delay in toxicity with HFIP pretreated $A \S_{42}$ may be due to a requirement for disaggregation of already formed nontoxic aggregates to toxic oligomers.

The aggregation of the HFIP and $\mathrm{NH}_{4} \mathrm{OH}$ pretreated $\mathrm{A} \beta_{42}$ peptide in the ThT and cell assays may be different due to the inherent complexity of cells and the effects of biological membranes, chaperones, metals and other proteins on aggregation kinetics of $A ß$. There is strong evidence to support that once the $A \beta_{42}$ peptide is added to cell cultures, it binds to the cell membrane and is internalised (Decker et al. 2010; Johnson et al. 2011). Cell bound A $\beta$ structures range from monomers to hexamers and greater (Johnson et al. 2011). Whilst the $A \beta$ structure(s) which cause toxicity are unknown, there is a sequeale of pathological events including binding of $A \beta$ to synapse receptors (NMDA - (De Felice et al. 2007), $\alpha 7$ Nicotinic acetylcholine receptor - (Wang et al. 2000)), an increase in calcium flux (Demuro et al. 2005; Simakova and Arispe 2007), depolarisation of cell membrane (Blanchard et al. 2002), increased reactive oxygen species (Parks et al. 2001) and impaired axonal transport (Wang et al. 2010) which leads to cell toxicity. Thus, data interpretation across the in vitro cell-free and cell assays should be made with caution.

Using the preparation of $A \beta_{42}$ described in the present study, toxicity is observed at 72-96 $\mathrm{h}$ posttreatment with no toxicity at an earlier time point $(48 \mathrm{~h})$. The 72-96 $\mathrm{h}$ time frame for toxicity is consistent with that reported by others (Fezoui et al. 2000; Barnham et al. 2003; Hung et al. 2008; Ciccotosto et al. 2011; Benilova et al. 2012). Studies that show A $\beta$ toxicity in neuronal cultures after 1-24 h could reflect peptide 
with residual HFIP which is toxic (at concentrations $>40 \mathrm{mM}$ ) to SHSY5Y cells within the $24 \mathrm{~h}$ time (Capone et al. 2009). We hypothesize that the greater toxicity of $\mathrm{NH}_{4} \mathrm{OH}$ pretreated $\mathrm{A} ß$ at lower concentrations and earlier time points is due to a greater concentration of effective (toxic) Aß. After HFIP treatment $\sim 60 \%$ of the $A ß$ were trapped as high molecular weight oligomers; provided this is also the case in cell experiments, these high molecular weight oligomers were not immediately toxic to PC12 cultures and thus additional time may be required for the high molecular weight oligomers to transition to the toxic intermediate. Alternatively, after HFIP treatment $\sim 40 \%$ of the total Aß concentration were low molecular weight oligomers which may be too dilute to induce a toxic response in PC12 cultures. In general, these data indicate that the starting oligomeric status of $A ß$ is an important factor for the observed toxicity.

In conclusion, we find that the use of HFIP alone is inappropriate for the stated purpose of producing a seed free solution of $A ß$. We also find that ammonium hydroxide is a much more effective pretreatment which produces a mostly seed free solution of $A ß$ upon resuspension with a sodium hydroxide protocol. We suggest that this approach is a much more appropriate treatment for biophysical and cell biology experiments of Aß. 


\section{References.}

Ahmed, M., J. Davis, D. Aucoin, T. Sato, S. Ahuja, S. Aimoto, J. I. Elliott, W. E. Van Nostrand and S. O. Smith (2010). "Structural conversion of neurotoxic amyloid-beta(1-42) oligomers to fibrils." Nature structural \& molecular biology 17(5): 561-567.

Barnham, K. J., G. D. Ciccotosto, A. K. Tickler, F. E. Ali, D. G. Smith, N. A. Williamson, Y. H. Lam, D. Carrington, D. Tew, G. Kocak, I. Volitakis, F. Separovic, C. J. Barrow, J. D. Wade, C. L. Masters, R. A. Cherny, C. C. Curtain, A. I. Bush and R. Cappai (2003). "Neurotoxic, redox-competent Alzheimer's beta-amyloid is released from lipid membrane by methionine oxidation." $\mathrm{J}$ Biol Chem 278(44): 42959-42965.

Benilova, I., E. Karran and B. De Strooper (2012). "The toxic Abeta oligomer and Alzheimer's disease: an emperor in need of clothes." Nat Neurosci 15(3): 349-357.

Blanchard, B. J., V. L. Thomas and V. M. Ingram (2002). "Mechanism of membrane depolarization caused by the Alzheimer Abeta1-42 peptide." Biochem Biophys Res Commun 293(4): 1197-1203.

Broersen, K., W. Jonckheere, J. Rozenski, A. Vandersteen, K. Pauwels, A. Pastore, F. Rousseau and J. Schymkowitz (2011). "A standardized and biocompatible preparation of aggregate-free amyloid beta peptide for biophysical and biological studies of Alzheimer's disease." Protein Eng Des Sel 24(9): 743-750.

Buck, M. (1998). "Trifluoroethanol and colleagues: cosolvents come of age. Recent studies with peptides and proteins." Q Rev Biophys 31(3): 297-355.

Capone, R., F. G. Quiroz, P. Prangkio, I. Saluja, A. M. Sauer, M. R. Bautista, R. S. Turner, J. Yang and M. Mayer (2009). "Amyloid-beta-induced ion flux in artificial lipid bilayers and neuronal cells: resolving a controversy." Neurotox Res 16(1): 1-13.

Ciccotosto, G. D., D. J. Tew, S. C. Drew, D. G. Smith, T. Johanssen, V. Lal, T. L. Lau, K. Perez, C. C. Curtain, J. D. Wade, F. Separovic, C. L. Masters, J. P. Smith, K. J. Barnham and R. Cappai (2011). "Stereospecific interactions are necessary for Alzheimer disease amyloid-beta toxicity." Neurobiol Aging 32(2): 235-248.

Davis, R. C., I. T. Marsden, M. T. Maloney, L. S. Minamide, M. Podlisny, D. J. Selkoe and J. R. Bamburg (2011). "Amyloid beta dimers/trimers potently induce cofilin-actin rods that are inhibited by maintaining cofilin-phosphorylation." Mol Neurodegener 6: 10 .

De Felice, F. G., P. T. Velasco, M. P. Lambert, K. Viola, S. J. Fernandez, S. T. Ferreira and W. L. Klein (2007). "Abeta oligomers induce neuronal oxidative stress through an $\mathrm{N}$-methyl-D-aspartate receptor-dependent mechanism that is blocked by the Alzheimer drug memantine." J Biol Chem 282(15): 11590-11601.

Decker, H., S. Jurgensen, M. F. Adrover, J. Brito-Moreira, T. R. Bomfim, W. L. Klein, A. L. Epstein, F. G. De Felice, D. Jerusalinsky and S. T. Ferreira (2010). "N-methyl-D-aspartate receptors are required for synaptic targeting of Alzheimer's toxic amyloid-beta peptide oligomers." J Neurochem 115(6): 1520-1529.

Demuro, A., E. Mina, R. Kayed, S. C. Milton, I. Parker and C. G. Glabe (2005). "Calcium dysregulation and membrane disruption as a ubiquitous neurotoxic mechanism of soluble amyloid oligomers." J Biol Chem 280(17): 17294-17300.

Doniach, S. (2001). "Changes in biomolecular conformation seen by small angle X-ray scattering." Chem Rev 101(6): 1763-1778.

Dubois, J., A. A. Ismail, S. L. Chan and Z. Ali-Khan (1999). "Fourier transform infrared spectroscopic investigation of temperature- and pressure-induced disaggregation of amyloid A." Scand J Immunol 49(4): 376-380. 
Dulbecco, R. and M. Vogt (1954). "Plaque formation and isolation of pure lines with poliomyelitis viruses." J Exp Med 99(2): 167-182.

Fezoui, Y., D. M. Hartley, J. D. Harper, R. Khurana, D. M. Walsh, M. M. Condron, D. J. Selkoe, P. T. Lansbury, Jr., A. L. Fink and D. B. Teplow (2000). "An improved method of preparing the amyloid beta-protein for fibrillogenesis and neurotoxicity experiments." Amyloid 7(3): 166-178.

Fezoui, Y. and D. B. Teplow (2002). "Kinetic studies of amyloid beta-protein fibril assembly. Differential effects of alpha-helix stabilization." J Biol Chem 277(40): 36948-36954.

Fulop, L., M. Zarandi, K. Soos and B. Penke (2006). "Self-assembly of Alzheimer's Disease-related Amyloid Peptides into Highly Ordered Nanostructures." Nanopages 1: 69-83.

Glenner, G. G. and C. W. Wong (1984). "Alzheimer's disease: initial report of the purification and characterization of a novel cerebrovascular amyloid protein." Biochem Biophys Res Commun 120(3): 885-890.

Hanslick, J. L., K. Lau, K. K. Noguchi, J. W. Olney, C. F. Zorumski, S. Mennerick and N. B. Farber (2009). "Dimethyl sulfoxide (DMSO) produces widespread apoptosis in the developing central nervous system." Neurobiol Dis 34(1): 1-10.

Hirota, N., K. Mizuno and Y. Goto (1997). "Cooperative alpha-helix formation of beta-lactoglobulin and melittin induced by hexafluoroisopropanol." Protein Sci 6(2): 416-421.

Huang, X., C. S. Atwood, R. D. Moir, M. A. Hartshorn, R. E. Tanzi and A. I. Bush (2004). "Trace metal contamination initiates the apparent auto-aggregation, amyloidosis, and oligomerization of Alzheimer's Abeta peptides." J Biol Inorg Chem 9(8): 954-960.

Hung, L. W., G. D. Ciccotosto, E. Giannakis, D. J. Tew, K. Perez, C. L. Masters, R. Cappai, J. D. Wade and K. J. Barnham (2008). "Amyloid-beta peptide (Abeta) neurotoxicity is modulated by the rate of peptide aggregation: Abeta dimers and trimers correlate with neurotoxicity." J Neurosci 28(46): 11950-11958.

Jiao, J., B. Xue, L. Zhang, Y. Gong, K. Li, H. Wang, L. Jing, J. Xie and X. Wang (2008). "Triptolide inhibits amyloid-beta1-42-induced TNF-alpha and IL-1beta production in cultured rat microglia." J Neuroimmunol 205(1-2): 32-36.

Johnson, R. D., J. A. Schauerte, K. C. Wisser, A. Gafni and D. G. Steel (2011). "Direct observation of single amyloid-beta(1-40) oligomers on live cells: binding and growth at physiological concentrations." PLoS One 6(8): e23970.

Kayed, R., Y. Sokolov, B. Edmonds, T. M. McIntire, S. C. Milton, J. E. Hall and C. G. Glabe (2004). "Permeabilization of lipid bilayers is a common conformation-dependent activity of soluble amyloid oligomers in protein misfolding diseases." J Biol Chem 279(45): 46363-46366.

Kirkitadze, M. D., G. Bitan and D. B. Teplow (2002). "Paradigm shifts in Alzheimer's disease and other neurodegenerative disorders: the emerging role of oligomeric assemblies." J Neurosci Res 69(5): 567-577.

Konarev, P. V., V. V. Volkov, A. V. Sokolova, M. H. J. Koch and D. I. Svergun (2003). "PRIMUS: a Windows PC-based system for small-angle scattering data analysis." Journal of Applied Crystallography 36: 1277-1282.

Krakow, N. P. (1898). "Beitdige zur chemie der amyloidenartung." Arch. Exp. Pathol. Pharmakol. 40: 195-220.

Lambert, M. P., K. L. Viola, B. A. Chromy, L. Chang, T. E. Morgan, J. Yu, D. L. Venton, G. A. Krafft, C. E. Finch and W. L. Klein (2001). "Vaccination with soluble Abeta oligomers generates toxicity-neutralizing antibodies." J Neurochem 79(3): 595-605. 
Lame, M. E., E. E. Chambers and M. Blatnik (2011). "Quantitation of amyloid beta peptides Abeta(1-38), Abeta(1-40), and Abeta(1-42) in human cerebrospinal fluid by ultra-performance liquid chromatography-tandem mass spectrometry." Anal Biochem 419(2): 133-139.

Lesne, S., M. T. Koh, L. Kotilinek, R. Kayed, C. G. Glabe, A. Yang, M. Gallagher and K. H. Ashe (2006). "A specific amyloid-beta protein assembly in the brain impairs memory." Nature 440(7082): 352-357.

Masters, C. L., G. Simms, N. A. Weinman, G. Multhaup, B. L. McDonald and K. Beyreuther (1985). "Amyloid plaque core protein in Alzheimer disease and Down syndrome." Proc Natl Acad Sci U S A 82(12): 4245-4249.

McColl, G., B. R. Roberts, A. P. Gunn, K. A. Perez, D. J. Tew, C. L. Masters, K. J. Barnham, R. A. Cherny and A. I. Bush (2009). "The Caenorhabditis elegans A beta 1-42 model of Alzheimer disease predominantly expresses A beta 3-42." J Biol Chem 284(34): 22697-22702.

McLean, C. A., R. A. Cherny, F. W. Fraser, S. J. Fuller, M. J. Smith, K. Beyreuther, A. I. Bush and C. L. Masters (1999). "Soluble pool of Abeta amyloid as a determinant of severity of neurodegeneration in Alzheimer's disease." Annals of neurology 46(6): 860-866.

Mertens, H. D. and D. I. Svergun (2010). "Structural characterization of proteins and complexes using small-angle X-ray solution scattering." J Struct Biol 172(1): 128-141.

Nichols, M. R., M. A. Moss, D. K. Reed, S. Cratic-McDaniel, J. H. Hoh and T. L. Rosenberry (2005). "Amyloid-beta protofibrils differ from amyloid-beta aggregates induced in dilute hexafluoroisopropanol in stability and morphology." J Biol Chem 280(4): 2471-2480.

Nichols, M. R., M. A. Moss, D. K. Reed, J. H. Hoh and T. L. Rosenberry (2005). "Amyloid-beta aggregates formed at polar-nonpolar interfaces differ from amyloid-beta protofibrils produced in aqueous buffers." Microsc Res Tech 67(3-4): 164-174.

Pachahara, S. K., N. Chaudhary, C. Subbalakshmi and R. Nagaraj (2012). "Hexafluoroisopropanol induces self-assembly of beta-amyloid peptides into highly ordered nanostructures." J Pept Sci 18(4): 233-241.

Parks, J. K., T. S. Smith, P. A. Trimmer, J. P. Bennett, Jr. and W. D. Parker, Jr. (2001). "Neurotoxic Abeta peptides increase oxidative stress in vivo through NMDA-receptor and nitric-oxide-synthase mechanisms, and inhibit complex IV activity and induce a mitochondrial permeability transition in vitro." $\mathrm{J}$ Neurochem 76(4): 1050-1056.

Perry, E. K., A. E. Oakley, J. M. Candy and R. H. Perry (1981). "Properties and possible significance of substance $P$ and insulin fibrils." Neurosci Lett 25(3): 321-325.

Petoukhov, M. V., D. Franke, A. V. Shkumatov, G. Tria, A. G. Kikhney, M. Gajda, C. Gorba, H. D. T. Mertens, P. V. Konarev and D. I. Svergun (2012). "New developments in the ATSAS program package for small-angle scattering data analysis." Journal of Applied Crystallography 45: 342-350.

Petoukhov, M. V., P. V. Konarev, A. G. Kikhney and D. I. Svergun (2007). "ATSAS 2.1 towards automated and web-supported small-angle scattering data analysis." Journal of Applied Crystallography 40: S223-S228.

Pras, M., D. Zucker-Franklin, A. Rimon and E. C. Franklin (1969). "Physical, chemical, and ultrastructural studies of water-soluble human amyloid fibrils. Comparative analyses of nine amyloid preparations." J Exp Med 130(4): 777-796. 
Putnam, C. D., M. Hammel, G. L. Hura and J. A. Tainer (2007). "X-ray solution scattering (SAXS) combined with crystallography and computation: defining accurate macromolecular structures, conformations and assemblies in solution." $\underline{Q} \mathrm{Rev}$ Biophys 40(3): 191-285.

Rangachari, V., D. K. Reed, B. D. Moore and T. L. Rosenberry (2006). "Secondary structure and interfacial aggregation of amyloid-beta(1-40) on sodium dodecyl sulfate micelles." Biochemistry 45(28): 8639-8648.

Ryan, D. A., W. C. Narrow, H. J. Federoff and W. J. Bowers (2010). "An improved method for generating consistent soluble amyloid-beta oligomer preparations for in vitro neurotoxicity studies." Journal of neuroscience methods 190(2): 171-179.

Ryan, T. M., A. Friedhuber, M. Lind, G. J. Howlett, C. Masters and B. R. Roberts (2012). "Small Amphipathic Molecules Modulate Secondary Structure and Amyloid Fibril-forming Kinetics of Alzheimer Disease Peptide Abeta1-42." J Biol Chem 287(20): 16947-16954.

Sahoo, B., S. Nag, P. Sengupta and S. Maiti (2009). "On the stability of the soluble amyloid aggregates." Biophysical journal 97(5): 1454-1460.

Shen, C. L. and R. M. Murphy (1995). "Solvent effects on self-assembly of beta-amyloid peptide." Biophys J 69(2): 640-651.

Shirahama, T. and A. S. Cohen (1967). "Reconstitution of amyloid fibrils from alkaline extracts." J Cell Biol 35(2): 459-464.

Simakova, O. and N. J. Arispe (2007). "The cell-selective neurotoxicity of the Alzheimer's Abeta peptide is determined by surface phosphatidylserine and cytosolic ATP levels. Membrane binding is required for Abeta toxicity." J Neurosci 27(50): 13719-13729.

Stine, W. B., Jr., K. N. Dahlgren, G. A. Krafft and M. J. LaDu (2003). "In vitro characterization of conditions for amyloid-beta peptide oligomerization and fibrillogenesis." J Biol Chem 278(13): 11612-11622.

Teplow, D. B. (2006). "Preparation of amyloid beta-protein for structural and functional studies." Methods Enzymol 413: 20-33.

Walsh, D. M., A. Lomakin, G. B. Benedek, M. M. Condron and D. B. Teplow (1997). "Amyloid beta-protein fibrillogenesis. Detection of a protofibrillar intermediate." $\mathbf{J}$ Biol Chem 272(35): 22364-22372.

Wang, H. Y., D. H. Lee, M. R. D'Andrea, P. A. Peterson, R. P. Shank and A. B. Reitz (2000). "beta-Amyloid(1-42) binds to alpha7 nicotinic acetylcholine receptor with high affinity. Implications for Alzheimer's disease pathology." J Biol Chem 275(8): 5626-5632.

Wang, X., G. Perry, M. A. Smith and X. Zhu (2010). "Amyloid-beta-derived diffusible ligands cause impaired axonal transport of mitochondria in neurons." Neurodegener Dis 7(1-3): 56-59.

Williams, T. L., I. J. Day and L. C. Serpell (2010). "The effect of Alzheimer's Abeta aggregation state on the permeation of biomimetic lipid vesicles." Langmuir 26(22): 17260-17268.

Yoda, M., T. Miura and H. Takeuchi (2008). "Non-electrostatic binding and self-association of amyloid beta-peptide on the surface of tightly packed phosphatidylcholine membranes." Biochem Biophys Res Commun 376(1): 56-59.

Yu, L., R. Edalji, J. E. Harlan, T. F. Holzman, A. P. Lopez, B. Labkovsky, H. Hillen, S. Barghorn, U. Ebert, P. L. Richardson, L. Miesbauer, L. Solomon, D. Bartley, K. Walter, R. W. Johnson, P. J. Hajduk and E. T. Olejniczak (2009). "Structural characterization of a soluble amyloid beta-peptide oligomer." Biochemistry 48(9): 1870-1877. 
Zagorski, M. G. and C. J. Barrow (1992). "NMR studies of amyloid beta-peptides: proton assignments, secondary structure, and mechanism of an alpha-helix----beta-sheet conversion for a homologous, 28-residue, N-terminal fragment." Biochemistry 31(24): 5621-5631.

Zagorski, M. G., J. Yang, H. Shao, K. Ma, H. Zeng and A. Hong (1999). "Methodological and chemical factors affecting amyloid beta peptide amyloidogenicity." Methods Enzymol 309: 189-204. 
Figure 1. HFIP treatment significantly enhances the rate of fibril formation. A) Analysis of HFIP, $\mathrm{NH}_{4} \mathrm{OH}$ effect on the aggregation kinetics of $\mathrm{A} \beta_{42}$ by ThT fluorescence time course. $\mathrm{A} \beta_{42}(5 \mu \mathrm{M})$ treated with HFIP (red circles, $\mathrm{t}^{1} \frac{1}{2} \sim 9 \pm 1.9 \mathrm{~h}$ ), $\mathrm{NH}_{4} \mathrm{OH}$ (blue circles, $\mathrm{t}^{1} \frac{1}{2}$ $\sim 16.2 \pm 1.3 \mathrm{~h}$ ), or not treated at all (green circles, $\mathrm{t}^{1} \frac{2}{2} \sim 15 \pm 2.6 \mathrm{~h}$ ) prior to suspension into PBS.

Figure 2: Pretreatment method determines the starting aggregation state of $A \beta_{42}$. A) Hydrodynamic radii were determined with dynamic light scattering measurements of $A \beta_{42}$ (100 $\mu \mathrm{M})$ after treatment with HFIP (red line) or $\mathrm{NH}_{4} \mathrm{OH}$ (blue line). B) Analysis of size distribution of HFIP (blue line) or $\mathrm{NH}_{4} \mathrm{OH}$ (red line) treated $\mathrm{A} \beta_{42}(200 \mu \mathrm{M})$ solutions by SEC using Superdex S200 media.

Figure 3: Pretreatment method determines the starting aggregation state of $A \beta_{42}$ as determined by transmission electron microscopy. A \& B) Micrographs from TEM analysis of HFIP (A) and $\mathrm{NH}_{4} \mathrm{OH}(\mathrm{B})$ pretreated $\mathrm{A}_{42}$ as prepared for SEC and ThT, after $6 \mathrm{~h}$ of incubation. C \& D) Further micrographs were acquired for samples prepared for DLS pretreated with HFIP (C) or $\mathrm{NH}_{4} \mathrm{OH}$ (D) Images captured 20 min post preparation. Scale bar $=200 \mathrm{~nm}$.

Figure 4: Small angle X-ray scattering analysis of the peptide treatments. $\mathrm{NH}_{4} \mathrm{OH}$ treated (A), HFIP treated (B) and untreated (C) A $\beta_{42}(220 \mu \mathrm{M})$ solutions. Panel D shows a ln/linear plot of the data for untreated (green), $\mathrm{NH}_{4} \mathrm{OH}$ (blue) and HFIP (red) treated $\mathrm{A} ß$ over the range 0.001> $q>0.1$. For comparison the scattering curve of the structured and non-aggregated ribonuclease A (dotted line) is also plotted. Panel E shows the corresponding Kratky plots of the data (untreated: green line, HFIP treated: red line and $\mathrm{NH}_{4} \mathrm{OH}$ treated: blue line).

Figure 5: Viability of PC12 cells assessed using the CCK-8 reagent. (A) PC12 cell viability after treatment with $\mathrm{NH}_{4} \mathrm{OH}$ and HFIPpretreated $\mathrm{A} \beta_{42}(10-20 \mu \mathrm{M})$ for $48 \mathrm{~h}(\mathrm{~B})$ PC12 cell viability after treatment with $\mathrm{NH}_{4} \mathrm{OH}$ and HFIPpretreated $\mathrm{A} \beta_{42}(10-20 \mu \mathrm{M})$ for $72 \mathrm{~h}$. (C) PC12 cell viability after treatment with $\mathrm{NH}_{4} \mathrm{OH}$ and HFIPpretreated $\mathrm{A} \beta_{42}(10-20 \mu \mathrm{M})$ for 96 h. The toxin controls, staurosporine (Stsp, $1 \mu \mathrm{M}$ ) and Triton X-100 (TX-100, 0.1\%), reduce the cell viability by $\geq 99 \%$. Data represent the mean \pm SEM of 24 experiments 
performed in triplicate $(\mathrm{n}=612)$. $* * * p<0.001$ for the $\mathrm{A} \beta_{42}$ vs the vehicle treated cells. Grey bars $=$ HFIPpretreated $A \beta_{42}$.

Supplementary Figure 1: Examples of the spread of data acquired by DLS. Plotted are the two extremes of the data (smallest radii observed blue, largest distribution, orange) and the most commonly observed distribution for both HFIP (A) and $\mathrm{NH}_{4} \mathrm{OH}$ (B) treated $\mathrm{A} \Omega$ (black). These datasets indicate that the HFIP is consistently distributed over a larger range of radii then the $\mathrm{NH}_{4} \mathrm{OH}$ treated peptide. 


\section{Figure 1}

HFIP treatment significantly enhances the rate of fibril formation

A) Analysis of HFIP, $\mathrm{NH}_{4} \mathrm{OH}$ effect on the aggregation kinetics of $\mathrm{A}_{42}$ by ThT fluorescence time course. $\mathrm{A} \beta_{42}(5 \mu \mathrm{M})$ treated with HFIP (red circles, $\mathrm{t}^{1} \frac{1}{2} \sim 9 \pm 1.9$ h), $\mathrm{NH}_{4} \mathrm{OH}$ (blue circles, $\mathrm{t}^{1 / 2} \sim 16.2 \pm$ $1.3 \mathrm{~h}$ ), or not treated at all (green circles, $\mathrm{t}^{1} \frac{2}{2} \sim 15 \pm 2.6 \mathrm{~h}$ ) prior to suspension into PBS.

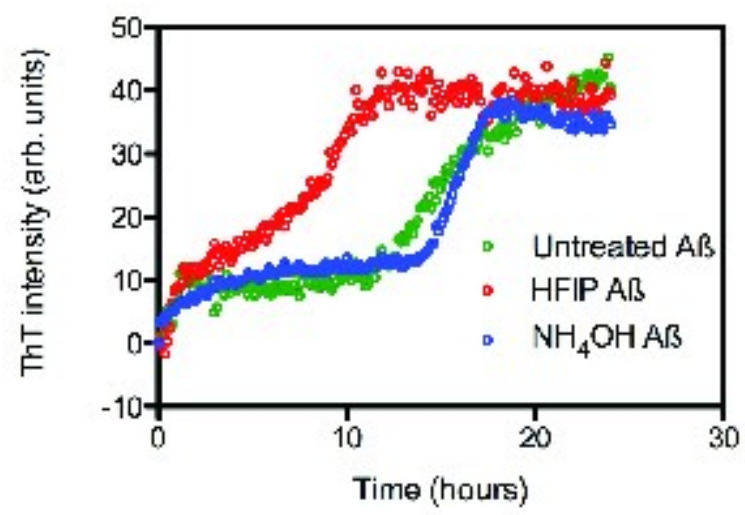




\section{Figure 2}

Pretreatment method determines the starting aggregation state of $A ß_{42}$

A) Hydrodynamic radii were determined with dynamic light scattering measurements of $A \beta_{42}(100$ $\mu \mathrm{M}$ ) after treatment with HFIP (red line) or $\mathrm{NH}_{4} \mathrm{OH}$ (blue line). B) Analysis of size distribution of HFIP (blue line) or $\mathrm{NH}_{4} \mathrm{OH}$ (red line) treated $\mathrm{A}_{42}(200 \mu \mathrm{M})$ solutions by SEC using Superdex S200 media.
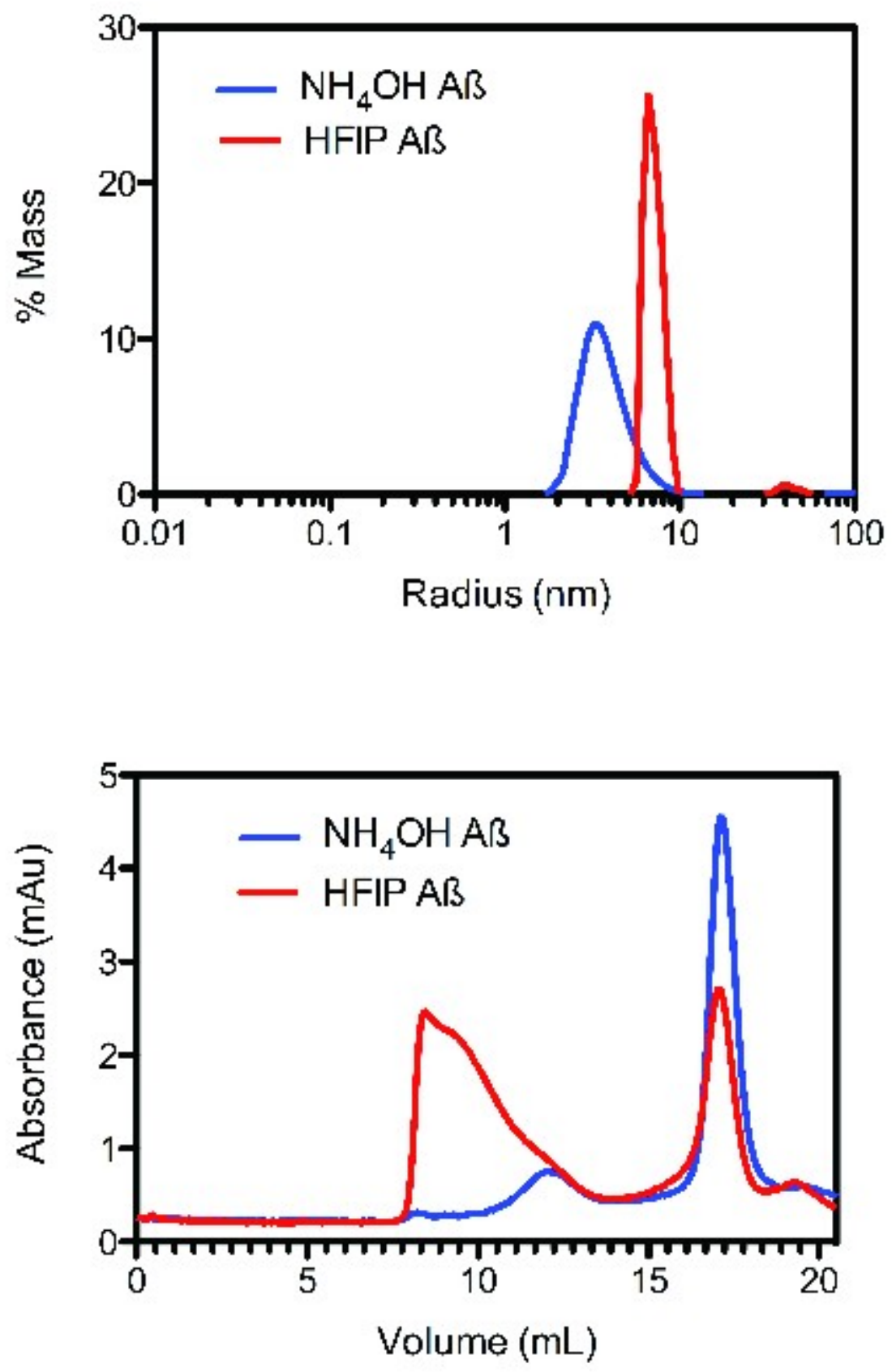


\section{Figure 3}

Small angle X-ray scattering analysis of the peptide treatments.

$\mathrm{NH}_{4} \mathrm{OH}$ treated (A), HFIP treated (B) and untreated (C) $\mathrm{A} \beta_{42}(220 \mu \mathrm{M})$ solutions. Panel D shows a In/linear plot of the data for untreated (green), $\mathrm{NH}_{4} \mathrm{OH}$ (blue) and HFIP (red) treated Aß over the range $0.001>q>0.1$. For comparison the scattering curve of the structured and non-aggregated ribonuclease A (dotted line) is also plotted. Panel E shows the corresponding Kratky plots of the data (untreated: green line, HFIP treated: red line and $\mathrm{NH}_{4} \mathrm{OH}$ treated: blue line).
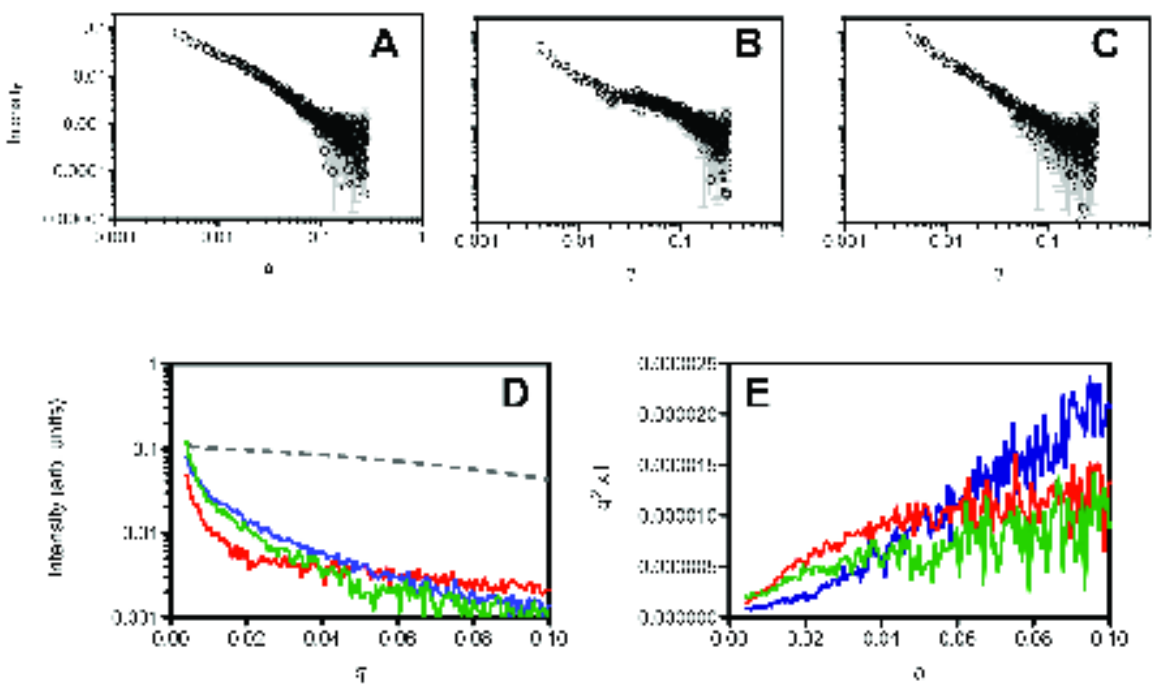


\section{Figure 4}

Pretreatment method determines the starting aggregation state of $A \aleph_{42}$ as determined by transmission electron microscopy.

. A \& B) Micrographs from TEM analysis of $\mathrm{HFIP}(\mathrm{A})$ and $\mathrm{NH}_{4} \mathrm{OH}(\mathrm{B})$ pretreated $\mathrm{Aß}_{42}$ as prepared for SEC and ThT, after $6 \mathrm{~h}$ of incubation. C \& D) Further micrographs were acquired for samples prepared for DLS pretreated with HFIP (C) or $\mathrm{NH}_{4} \mathrm{OH}$ (D) Images captured 20 min post preparation.

Scale bar $=200 \mathrm{~nm}$
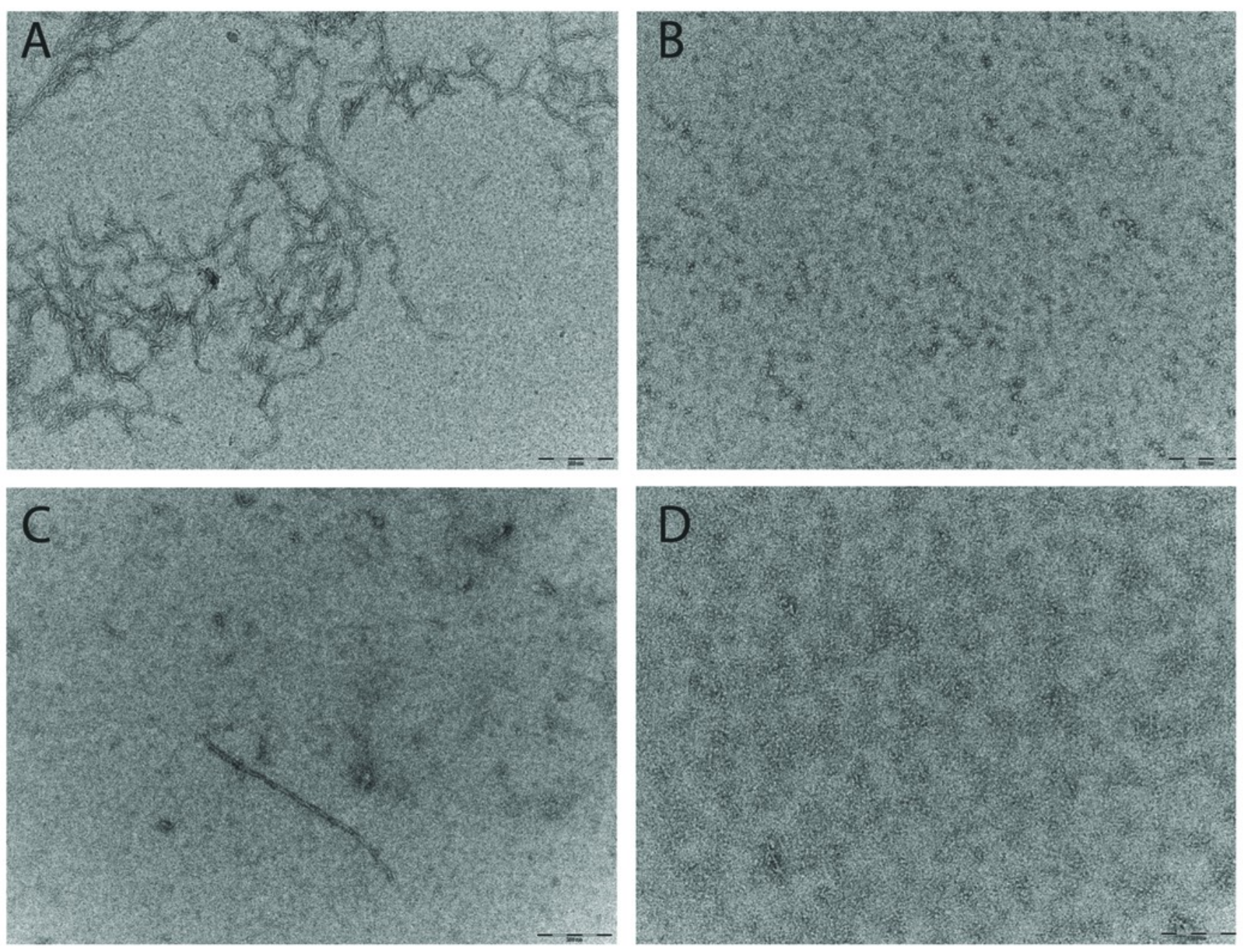


\section{Figure 5}

Viability of PC12 cells assessed using the CCK-8 reagent.

(A) PC12 cell viability after treatment with $\mathrm{NH}_{4} \mathrm{OH}$ - and HFIP-pretreated $\mathrm{A} \beta_{42}(10-20 \mu \mathrm{M})$ for $48 \mathrm{~h}$

(B) PC12 cell viability after treatment with $\mathrm{NH}_{4} \mathrm{OH}$ - and HFIP-pretreated $\mathrm{A} \beta_{42}(10-20 \mu \mathrm{M})$ for $72 \mathrm{~h}$.

(C) PC12 cell viability after treatment with $\mathrm{NH}_{4} \mathrm{OH}$ - and HFIP pretreated $\mathrm{A} \beta_{42}(10-20 \mu \mathrm{M})$ for $96 \mathrm{~h}$.

The toxin controls, staurosporine (Stsp, $1 \mu \mathrm{M}$ ) and Triton X-100 (TX-100, 0.1\%), reduce the cell viability by $\geq 99 \%$. Data represent the mean \pm SEM of 2-4 experiments performed in triplicate $(n=6-12)$. *** $p<0.001$ for the $\mathrm{A} \beta_{42}$ vs the vehicle treated cells. Grey bars $=$ HFIP-pretreated $\mathrm{A} \beta_{42}$. 
A

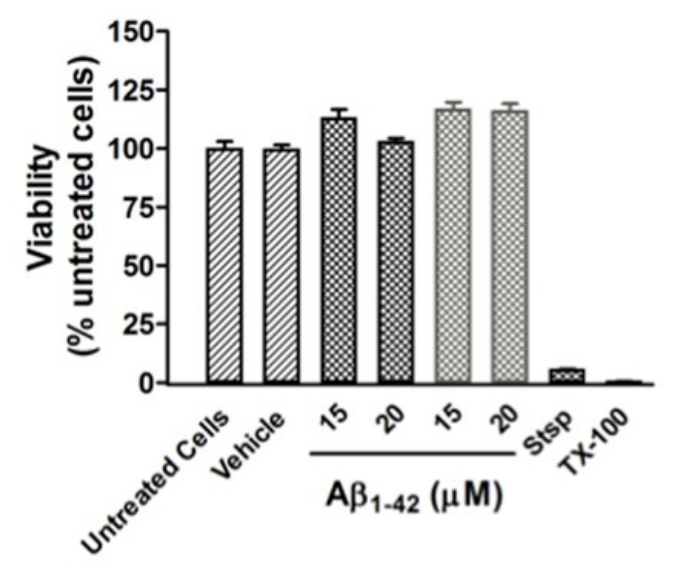

B

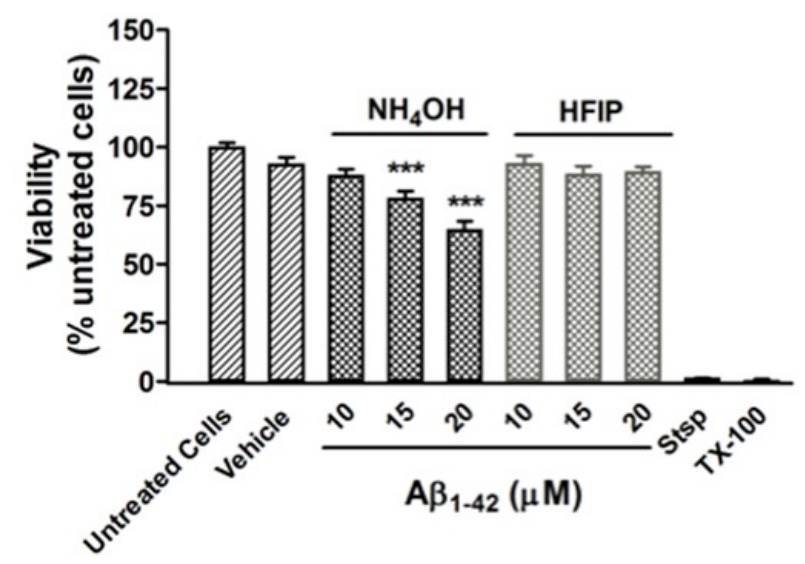

C

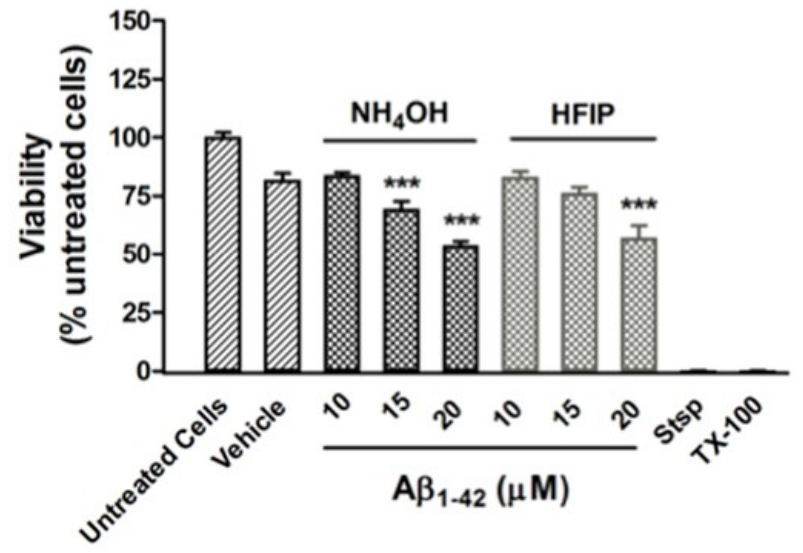

